American Journal of Agricultural and Biological Sciences 4 (2): 92-96, 2009

ISSN 1557-4989

(C) 2009 Science Publications

\title{
Study of Performance Parameters of Threshing Unit in a Single Plant Thresher
}

\author{
Ezzatollah Askari Asli-Ardeh, Yousef Abbaspour-Gilandeh and Saeid Abbasi \\ Assistant Professors and Graduate Student of Agricultural Machinery Department, College of \\ Agriculture, University of Mohaghegh Ardabili, Ardabil, Iran
}

\begin{abstract}
Problem Statement: The rice is the one of important crop in the word which is cultivated at the extensive area of Iran. Yield of crop is a factor which is investigated in the breading researches. Usually, for threshing of crops at these studies, single plant thresher is used. Approach: In this study, the threshing unit of a type of single plant thresher (Almaco SPT-SEX model) was evaluated. The effects of drum speed, crop moisture content and variety were investigated on the threshing loss, damaged grain percent and power requirements of threshing unit. Tests were arranged as a split- split plot fitted into randomized completed block with three replications. To compare the means, Duncan's Multiple Range Test was used. Results: Results showed that the effects of variety on the damaged grains percent and power requirement of the threshing unit were significant at probability level of $1 \%$ and 5\%, respectively. The effect of crop moisture content was significant at probability level of $1 \%$ on the threshing loss and power requirement. Conclusion/Recommendation: With increasing of drum speed at all varieties, threshing loss decreased. At all drum speed levels, by increasing drum speed, damaged grains percent increased. At each drum speed, the mean of power requirement at wet condition of paddy was significantly higher than dry condition of paddy.
\end{abstract}

Key words: Thresher, rice, threshing loss, damaged grains percent, power requirement

\section{INTRODUCTION}

Rice is one of the oldest known crops to have been cultivated by human. This cereal foodstuff is a staple food crop in many parts of the world, including $\operatorname{Iran}^{[2,5]}$. Researches have been conducted at it's cultivate different stages including of planting, breeding, production, harvesting and post harvesting in the international rice research institute and rice research the institute of $\operatorname{Iran}^{[1-3,5,9,10,13]}$. The yield of crop is always considered as an important independent factor. To determine yield crop, especially in breading researches, a little crop (single plant) is threshed. This machine is named as single plant thresher. At this study, the threshing unit of a single plant thresher (Almaco spt-sex model) was investigated. Effects of drum speed, crop moisture content and variety were investigated on the threshing loss, damaged grains percent and power requirement according to the previous researches ${ }^{[1,3,9,10,13]}$. The structure of the threshing unit of single plant thresher differs with common thresher. Concave is placed at above drum. Square spiked tooth are installed on its internal surface. Drum rotates in clock wise. However, excessive researches have been conducted about the paddy threshers but there is not any research about this type of threshing unit in single plant thresher Saeed et al. ${ }^{[11]}$ evaluated a hold paddy thresher. He showed that the threshing efficiency $99.2 \%$ is obtained at drum speed of $500 \mathrm{rpm}$. Datt and Annamalia ${ }^{[6]}$ designed and developed a straight through peg tooth type thresher for paddy. At their tests with five varieties paddy and peripheral speed of drum of 17 $\mathrm{m} \mathrm{sec}^{-1}$, concluded that even the wet crop with moisture content of grain and straw as high as 25 and $74 \%$, respectively, could be handled by this thresher with threshing efficiency $99.98 \%$ without damaged grain ${ }^{[6]}$.

\section{MATERIALS AND METHODS}

Required materials and instruments to accomplish this study include of the single plant threshing unit, digital wattmeter, digital tachometer, electrometer and belts and pulleys and varieties of paddy. Main parts this thresher consist of drum, concave, feeding tray, cleaning fan, chassis, collecting chute and grain speed reducer (Fig. 1).

Corresponding Author: Dr. Yousef Abbaspour-Gilandeh, Department of Agricultural Machinery, College of Agriculture, University of Mohaghegh Ardabili, Ardabil, Iran 
The length and diameter of drum were 330 and $110 \mathrm{~mm}$, respectively. The number of tooth fitted on drum was equal to 85 . The wrapping angle of concave was 115 degree. The concave as well as a cap was placed the top of drum. To accomplish experiments, samples were prepared from experimental farm of rice research institute, Rasht, Iran. The samples were manually harvested at 9-11 a.m. The grain moisture content was immediately measured by a digital moisture meter (model GMK-303). For determining of stalks moisture content was used by ASAE standard ${ }^{[4]}$. For creating other moisture levels (grain storage moisture level), samples spread on the flour till the grains receive to storage moisture level. Grain and stalks moisture content was presented in Table 1.

Procedure is in this manner that Single plant (a handle) is feed into threshing unit via feeding try. Grains are threshed as the result of the impact force of rotating drum. Then grains are felled on reducing roller. Here the speed of grains is reduced. Thereafter grains are cleaned by air current of fan. Cleaned grains are collected into the chute. A view of single plant thresher (Almaco apt-sex) was seen in Fig. 1. With attention the number of varieties (3 levels), moisture conditions (two levels), drum speeds (4 levels) and replications (3 levels), 72 tests were run. Varieties were including Hashemi, Khazar and bahar 1).

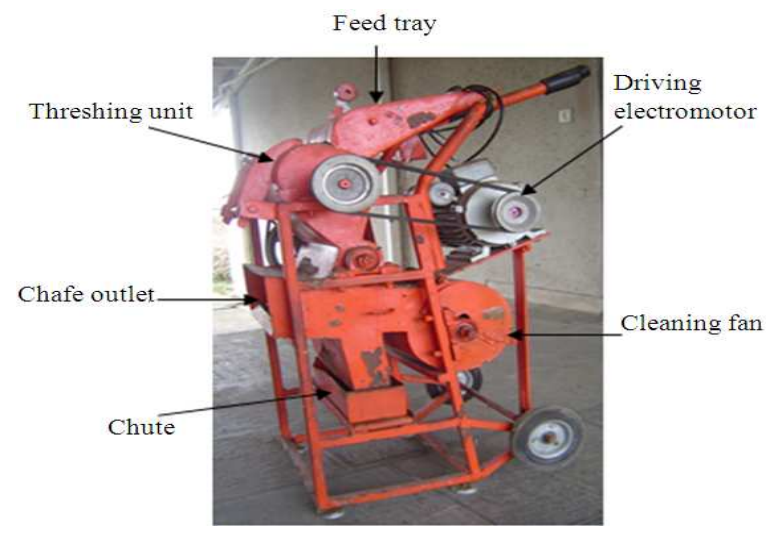

Fig. 1: Single plant thresher

Table 1: Grain and stalks moisture content of used varieties in experiments

\begin{tabular}{lllll}
\hline & \multicolumn{4}{c}{ Moisture content } \\
& Grain & & Stalk & \\
& -------------- \\
Varieties & Wet & Dry & Wet & Dry \\
\hline Khazar & 27.50 & 14.91 & 80.90 & 19.73 \\
Hashemi & 26.93 & 13.72 & 73.82 & 15.63 \\
Bahar1 & 26.72 & 13.24 & 72.81 & 14.81 \\
\hline
\end{tabular}

The levels of drum peripheral (tip tooth) were including 8, 11, 14 and $17 \mathrm{~m} \mathrm{sec}^{-1}$ for verifying drum speed, pulleys with different diameter were applied. These levels included nearly all drum speeds which other researchers ${ }^{[5-8,12]}$ applied for threshing of paddy. In the duration of each test, the maximum requirement power for threshing was measured and recorded by digital power meter. After from each test, remained grains on panicles were separated. The weight percent of them respect to total grains weight (threshed and no threshed grains) took as threshing loss. Also, poured grains in collecting chute were cleaned. To determine damaged grained percent, five samples $10 \mathrm{~g}$ were removed from among them. Then damaged grains were separated and weighted. After, experiments accomplishment and data collection, analyze of variance was accomplished separately for each dependent variable. Dependent variables included power requirement, threshing loss and damaged grains percent. Experiments were arranged as a split- split plot fitted into randomized complete block with three replications. To compare of the means, Duncan's multiple range test was used.

\section{RESULTS}

The result of the analysis of variance of the dependent variables has been showed in Table 2 .

Threshing loss: The results showed that the effects of independent variables (crop moisture content and drum speed) and their interactions were significant on the threshing loss except variety effects. The comparison results of the main effects means showed that threshing loss of dry paddy was higher than wet paddy with significant different $(\mathrm{p}<5 \%)$.

Table 2: Analysis of variance of threshing loss, damaged grains percent and MOG to grain ratio

\begin{tabular}{|c|c|c|c|c|}
\hline \multirow[b]{2}{*}{$\begin{array}{l}\text { Source of } \\
\text { Variation (SV) }\end{array}$} & \multirow[b]{2}{*}{$\begin{array}{l}\text { Degree of } \\
\text { freedom }(\mathrm{df})\end{array}$} & \multicolumn{2}{|r|}{ F ratio } & \multirow[b]{2}{*}{$\begin{array}{l}\text { Power } \\
\text { Requirement } \\
\text { (W) }\end{array}$} \\
\hline & & $\begin{array}{l}\text { Threshing } \\
\text { loss }(\%)\end{array}$ & $\begin{array}{l}\text { Damaged grains } \\
\text { percent }(\%)\end{array}$ & \\
\hline Replications (R) & 2 & $<1.00$ & $<1.00$ & $<1.00$ \\
\hline Variety (V) & 2 & $2.69^{\mathrm{ns}}$ & $8.886^{*}$ & $175.45^{* *}$ \\
\hline Error (a) & 4 & - & - & - \\
\hline Moisture (M) & 1 & $26.77 * *$ & $3.735^{\mathrm{ns}}$ & $52.32 * *$ \\
\hline$(\mathrm{M} \times \mathrm{V})$ & 2 & $22.39 * *$ & $11.199 * *$ & $1.34^{\mathrm{ns}}$ \\
\hline Error (b) & 6 & - & - & - \\
\hline Drum speed (S) & 3 & $102.89^{* *}$ & $328.060 * *$ & $214.47^{* *}$ \\
\hline$(\mathrm{V} \times \mathrm{S})$ & 6 & $4.25 * *$ & $2.538^{*}$ & $23.96^{* *} *$ \\
\hline$(\mathrm{M} \times \mathrm{S})$ & 3 & $10.21 * *$ & $0.432^{\text {ns }}$ & $12.23^{* *} *$ \\
\hline$(\mathrm{V} \times \mathrm{M} \times \mathrm{S})$ & 6 & $6.23 * *$ & $4.474 * *$ & $1.61^{\mathrm{ns}}$ \\
\hline Error $(\mathrm{c})$ & 36 & - & - & - \\
\hline Total & 71 & & & \\
\hline
\end{tabular}




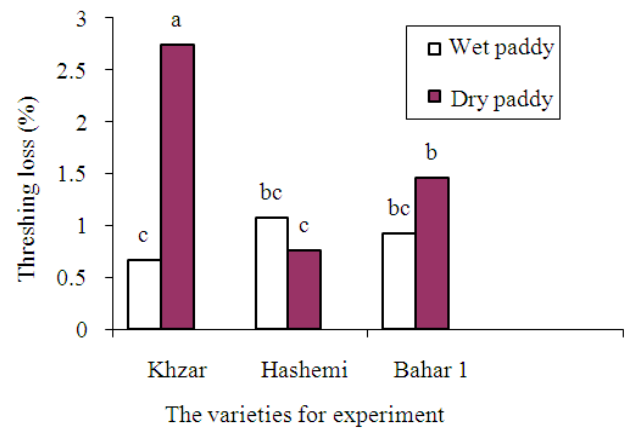

(a)

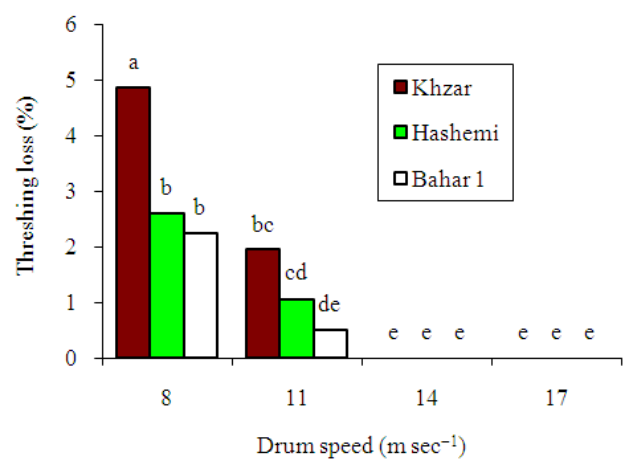

(b)

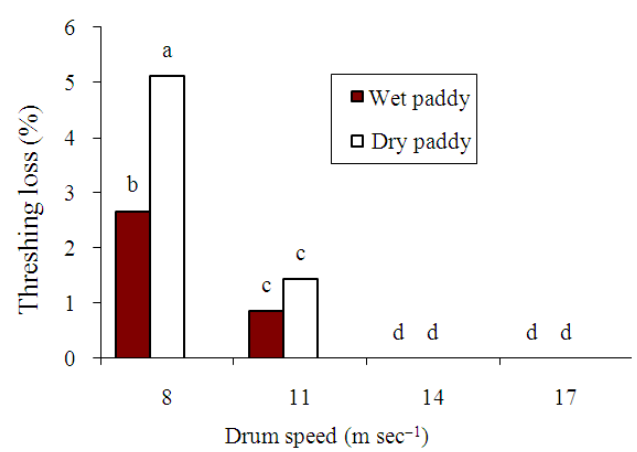

(c)

Fig. 2: The results of double interaction means on the threshing loss (dissimilar letters shows different significantly at probability level 5\%)

The results of comparison of interactions means of variety and paddy moisture condition revealed that only at experiments with Khazar variety, effects of the paddy moisture condition (wet and dry) has produced the significant different on the threshing loss (Fig. 2a).

The results of interaction mean comparison of drum speed and variety (Fig. 2b) showed that with increasing of drum speed at al variety, threshing loss was decreased as it was been zero at $14 \mathrm{~m} \mathrm{sec}^{-1}$. The result of interaction means comparison of paddy moisture condition and drum speed revealed which at all drum speed levels; threshing loss mean of wet paddy was lower than dry paddy (Fig. 2c). The different of effects dry paddy and wet paddy was significant $(\mathrm{p}<1 \%)$ only at drum speed $8 \mathrm{~m} \mathrm{sec}^{-1}$.

Damaged grain percent: As at Table 2 has been presented, the effects of variety and double interactions of this factor with others were significant. The effect of paddy moisture condition and the interactions of this factor (Fig. 3b) with the drum speed were not significant. The results of means comparison of double interactions were illustrated in Fig. 3.

Power requirement: The results of variance analysis (Table 2) revealed that the main effects of Variety (V), Moisture content (M) and the drum Speed (S) and also interactions $(\mathrm{V} \times \mathrm{S}$ and $\mathrm{M} \times \mathrm{S})$ were significant on the power requirement of threshing unit. The drum speed effect was significantly increased the power requirement. The highest (959.3) and lowest $(331.0 \mathrm{~W})$ power requirement take placed in drum speed of 17 and $8 \mathrm{~m} \mathrm{sec}^{-1}$, respectively. The mean comparison of interaction effects of variety and paddy moisture conditions showed that for all varieties, power requirement at wet condition of paddy was significantly higher than dry condition of paddy.

\section{DISCUSSION}

Threshing loss: The mentioned results in Fig. 2 for the threshing loss factor are similar to the result of ${ }^{[5,6,12]}$. With increasing of drum speed at all varieties, threshing loss was decreased (Fig. 2b). Hence with increasing drum speed, the impact force on panicles increased. The threshing loss means at tests with Khazar variety had been greatest from others (Fig. 2a). Then threshing force of this variety is more than for Hashemy and Bahar1 varieties. As results, at Khazar variety, the shattering habit of grain had been less. The highest and lowest means of threshing loss were allocated to Khazar (1.702) and Hashemi (0.914\%), respectively.

Damaged grain percent: As Showed in Fig. 3b, the effect of paddy moisture condition and the interactions of this factor with the drum speed were not significant. Therefore the strength of grains at varieties respect to impact force has been different. At all drum speed levels (Fig. 3a) increasing of the drum speed was caused the damaged grains percent increased. This is because of increasing of impact force on the grains. 


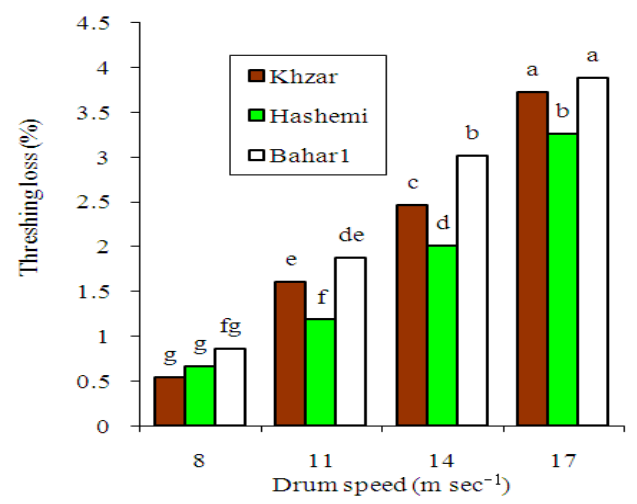

(a)

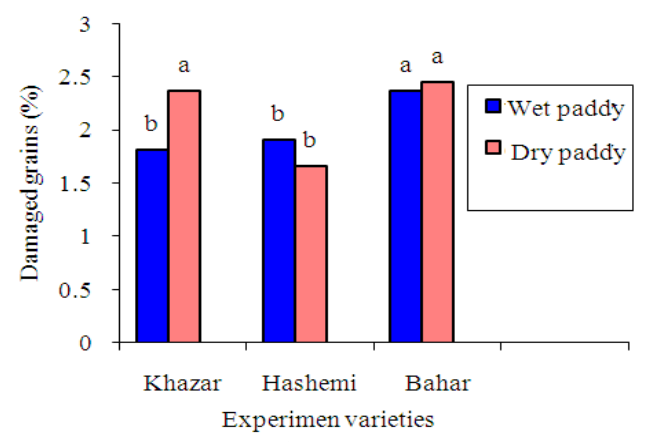

(b)

Fig. 3: The results of means comparison of double interactions on damaged grains percent (dissimilar letters shows different significantly at probability level 5\%)

The decreasing of moisture content of paddy was increased the damaged grains percent only at Khazar variety (Fig. 3b). Thus at this variety, the decreasing moisture content of grains was subtracted the strength of grains respect to the impact force.

Power requirement: The comparison of the main effects of the variables showed that the mean of power requirement was not different between Hashemi and Bahar 1 varieties. But it was different between Hashemi and Bahar 1 varieties.

The highest and lowest power requirement mean allocated to Khazar (830.3) and Hashemi (531.1 W) varieties, respectively. It is due to from higher detachment force of grain at Khazar variety and also the higher friction of panicles with threshing elements. The results of mean comparison of interaction effects (Fig. 4b) showed that at each of the drum speed, the mean of power requirement related to wet condition of paddy was significantly $(\mathrm{p}<5 \%)$ higher than dry condition of paddy. In general, the highest mean (1144 W) was obtained for Khazar variety at the wet condition.

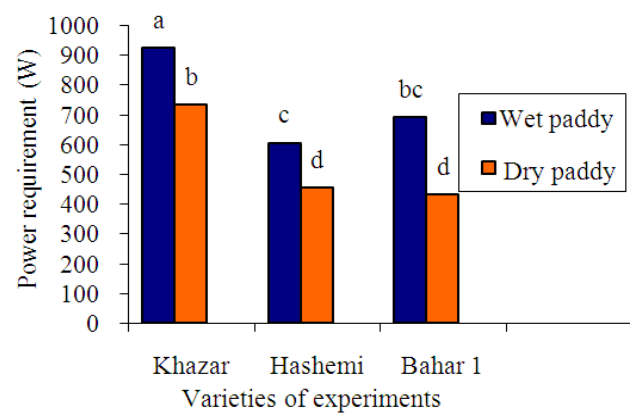

(a)

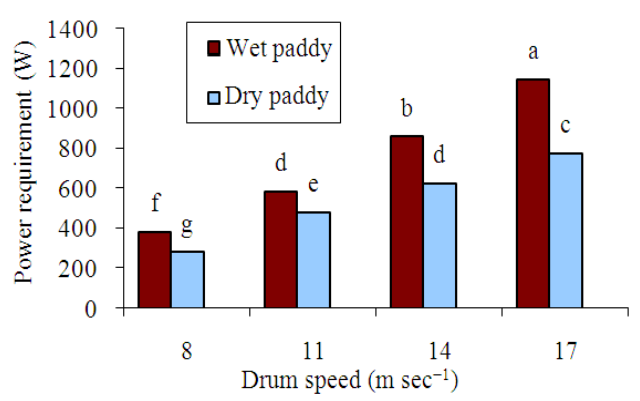

(b)

Fig. 4: The results of mean comparison of double interaction on the power requirement (dissimilar letters shows different significantly at probability level 5\%)

\section{CONCLUSION}

Overall these results of obtained from the study which has been summarized as follows:

- The threshing loss was different at wet and dry conditions of paddy

- Drum speed affects on threshing loss, damaged grains percent and power requirement

- In general, variety variable was not affected on the threshing loss

- The highest and lowest damaged grain percent was allocated to Bahar 1 and Khazar varieties, respectively

- Only at Khazar variety, to dry of paddy has increased the damaged grains percent

- Variety, paddy moisture condition and drum speed affected on the power requirement power of threshing unit

- The highest and lowest of power requirement obtained at tests with Khazar and Hashehi varieties, respectively

- Power requirement of threshing unit for wet paddy was higher than dry paddy 


\section{REFERENCES}

1. Andrews, S.B., T.J. Siebenmorgen, E.D. Vories, D.H. Loewer and A. Mauromoustakos, 1993. Effects of combine operating parameters on harvest loss and quality in rice. Trans. $\quad$ ASAE., 36: 1599-1607. http://cat.inist.fr/?aModele $=$ afficheN\&cpsidt=3917102

2. Araullo, E.V., B.D.E. Pada and M. Graham, 1976. Rice Post-Harvesting Technology. 1st Edn., International Development Research Center, Ottawa, pp: 67-85. ISBN: 0889360677.

3. Arnold, R.E. and J.R. Lake, 1965. Direct, indirect and double threshing in herbage seed production: I: S.48 timothy. J. Agric. Eng. Res., 10: 204-211. DOI: $10.1016 / 0021-8634(65) 90118-6$

4. ASAE Standards, 2003. ASAE S352.2: Moisture measurement-unground grain and seeds. St. Joseph, MI, USA. http://140.112.94.11/ dsfon/graindrying/ASAE/51 1.pdf

5. Askari Asli-Ardeh, E. and Y. Abbaspour-Gilandeh, 2008. Investigation of the effective factors on threshing loss, damaged grains percent and material other than grain to grain ratio on an auto head feed threshing unit. Am. J. Agric. Biol. Sci., 3: 699-705.

http://www.scipub.org/fulltext/AJAB/AJAB34699705.pdf

6. Datt, P. and S.J.K. Annamalia, 1991. Design and development of straight through peg tooth type thresher for paddy. Agric. Mech. Asia Afr. Latin Am., 22: 47-50. http://direct.bl.uk/bld/OrderDetails.do?did=2\&uin= 203860880

7. Ezaki, H., 1963. Threshing performance of Japanese type combine. Jap. Agric. Res., 7: 22-29. http://ss.jircas.affrc.go.jp/english/publication/jarq/0 7-1/07-1-025-030.pdf
8. Gummert, M., W. Muhlbure, W. Wacker and G.R. Quick, 1990. Performance and evaluation of IRRI axial-flow paddy thresher. Agric. Mech. Asia, Afr. Latin Am., 22: 47-50. http://www.cababstractsplus.org/abstracts/Abstract. aspx?AcNo=19922455415

9. Ichikawa, T., T. Sugiyama, H. Takahashi and S. Miyahara, 1990. Equipment for quantitative measurement of shattering habit of paddy. Jap. Agric. $\quad$ Res., 24: 34-42. http://ss.jircas.affrc.go.jp/english/publication/jarq/2 4-1/24-1-037-042.pdf

10. Klenin, N.I., I.F. Popov and V.A. Sakun, 1985. Agricultural Machines. 1st Edn., American Publishing Co. Pvt. Ltd., New Delhi, pp: 400-418. ISBN: 9061914485.

11. Saeed, M.A., A.S. Khan, H.A. Rizvi and T. Tanveer, 1995. Testing and evaluation of hold-on paddy thresher. Agric. Mech. Asia Afr. Latin Am., 26: 47-51. http://direct.bl.uk/bld/PlaceOrder. do?UIN $=028208388 \&$ ETOC $=\mathrm{EN} \&$ from $=$ searchen gine.

12. Sarwar, J.G. and A.U. Khan, 1987. Comparative performance of rasp-bar and wire-loop cylinders for threshing rice crop. Agric. Mech. Asia Afr. Latin Am., 18: 37-42. http://scholar.ilib.cn/AISSN 1002-6819(2008)03-0139-04.html

13. Suzuki, M., 1980. Performance of rice combine harvesters as evaluated by the national test in Japan. Jap. Agric. Res., 14: 20-23. http://ss.jircas.affrc.go.jp/english/publication/jarq/1 4-1/14-1-020-023.pdf 